WP 15_10

\author{
Pantelis Kalaitzidakis
}

University of Crete

Theofanis P. Mamuneas

University of Cyprus

Thanasis Stengos

University of Guelph

\title{
AN UPDATED RANKING OF ACADEMIC JOURNALS IN ECONOMICS
}

\section{Copyright belongs to the author. Small sections of the text, not exceeding three paragraphs, can be used} provided proper acknowledgement is given.

The Rimini Centre for Economic Analysis (RCEA) was established in March 2007. RCEA is a private, nonprofit organization dedicated to independent research in Applied and Theoretical Economics and related fields. RCEA organizes seminars and workshops, sponsors a general interest journal The Review of Economic Analysis, and organizes a biennial conference: The Rimini Conference in Economics and Finance (RCEF) . The RCEA has a Canadian branch: The Rimini Centre for Economic Analysis in Canada (RCEACanada). Scientific work contributed by the RCEA Scholars is published in the RCEA Working Papers and Professional Report series.

The views expressed in this paper are those of the authors. No responsibility for them should be attributed to the Rimini Centre for Economic Analysis. 


\title{
An Updated Ranking of Academic Journals in Economics*
}

\author{
Pantelis Kalaitzidakis \\ Theofanis P. Mamuneas \\ University of Crete \\ University of Cyprus \\ Thanasis Stengos \\ University of Guelph
}

April 2010

\begin{abstract}
We conduct an update of the ranking of economic journals by Kalaitzidakis, Mamuneas and Stengos (2003). However, our present study differs methodologically from that earlier study in an important dimension. We use a rolling window of years between 2003 and 2008, for each year counting the number of citations of articles published in the previous ten years. This allows us to obtain a smoother longer view of the evolution of rankings in the period under consideration and avoid the inherent randomness that may exist at any particular year. Using this framework we proceed to examine the relative ranking of the Canadian Journal of Economics over time. We find the Canadian Journal managed not only to maintain its relative position, but to also improve it over time.
\end{abstract}

\footnotetext{
${ }^{*}$ We like to thank Maria Ioannidou and Charalampos Karagiannakis for excellent research assistance. Partial financial support from the Canadian Economic Association is gratefully acknowledged.
} 


\section{Introduction}

There has been an important professional tradition within economics to rank journals and the literature on the subject has grown considerably in the past twenty years. Some important papers in the literature include Liebowitz and Palmer (1984), Laband and Piette (1994), Kalaitzidakis, Mamuneas and Stengos (2003), Palacio-Huerta and Volij (2004), Liner and Amin (2006), Kodrzycki and Yu (2006), Kóczy and Strobel (2007) and Ritzberger (2008). Journal rankings have been used as tools to evaluate the research performance of economics departments. They act as important signals for attracting new faculty and retaining older ones in highly ranked institutions and also attracting the best graduate students with academic aspirations.

An important argument in favor of journal rankings is the vast proliferation of new journals which makes the need for an objective comparison of the different research outlets imperative. It is the attempt to "objectify" scientific quality that makes the rankings exercises worth while as they foster the development of scientific standards and provide an indicator of scientific quality for those not only inside but also outside the profession. The objective premise on which rankings are based is that one paper cites the results that were obtained in another as these results were presumably important in the development of the arguments advanced in the current paper. It is the understanding that papers in a given field will quote the relevant literature in that field and any omissions are going to be attributed to random errors. Also, it is the case that certain pieces of work become such classics that there is no need to refer to the original source and they are simply referred to by name, e.g. the Solow-Swan growth model or Nash equilibrium. For the rest though, the assumption is that quality of a particular piece of work is captured in general by the citations that it generates.

In this paper we develop new journal rankings that are an updated version of the earlier work of Kalaitzidakis, Mamuneas and Stengos (2003). We use the same source of data from the Journal of Citation Reports $(J C R)$ for the same category economics using the same iterative eigenfactor methodology and 
corrections to arrive at the current rankings. However, the present study differs methodologically from that earlier study in an important dimension. We use a rolling window of years between 2003 and 2008 to conduct our analysis, for each year counting the number of citations of articles published in the previous ten years. For example, in 2008 we count the number of times articles published in 2008 cited articles published in the ten year period, 2008 to 1999. Similarly for 2003, we count the times articles published in 2003 cited articles published in the ten year period, 2003 to 1994 and similarly for all the in between years. This allows us to obtain a smoother longer view of the evolution of rankings in the period under consideration and avoid the inherent randomness that may exist at any particular year due to the given set of journals used in the analysis of that year. Over time, there is a proliferation of new journals and in our analysis in 2008 there are 209 journals, whereas in 2003 only 169. Overtime, the effect of such differences in size of the set of journals is smoothed out and it becomes less of an issue.

We further proceed to examine the relative performance of the Canadian Journal of Economics ( $C J E$ ) over this period. The $C J E$ is the official journal of the Canadian Economics Association and it appears in its current form since 1968. In earlier rankings, the CJE was ranked fairly high, see for example Liebowitz and Palmer (1984), where it was ranked just outside the top quartile group of journals (28th out of 108 journals), but it slipped to about the median in subsequent rankings, see Laband and Piette (1994), where it fell to the 62nd position out of 130 journals. However, it recovered to nearly the top quartile in Kalaitzidakis et al (2003), (42nd position out of a set of 159$)$. In this paper, we find that the above relative improvement was not an aberration and that over the 2003 to 2008 period the CJE has not only maintained but also improved its relative position in the top quartile group of economic journals.

The paper is organized as follows. The next section provides the methodology that we employ to arrive at the new journal rankings. We provide details of the way that we arrive at these rankings and the data sources that are used. In the subsequent section we discuss the results. Finally we conclude. 


\section{Methodology}

\section{$2.1 \quad$ Journal Rankings}

Below we outline in more detail the methodology we have employed in arriving at a more representative and accurate journal ranking.

The data source that we use to count the number of citations received by economic journals is the $(J C R)$. For each year between 2003 and 2008 each article published in a given journal cites articles that have been published in the preceding ten years in other journals. All these citations are counted and provide the basis for the ranking analysis. In order to be consistent with Kalaitzidakis, Mamuneas and Stengos (2003) we only use the category economics in $(J C R)$. That implies that we exclude journals that are core journals in other related disciplines, such as the Journal of Finance. However, the Journal of Financial Economics is included in this category.

In order to correct for self-citations and the age of a journal we exclude selfcitations and all the citations of articles published outside the ten year horizon period that is used for each year of the analysis. Self-citations are excluded, since they bias the rankings (due to the common tendency of journals to cite their own articles more often). Similarly, given the establishment of many new

journals in the last twenty years by ignoring citations older than ten years, we place more or less all journals on an equal footing, since older journals tend to accumulate more citations. We also correct for size of journal, as "bigger" journals that tend to publish more articles, also attract more citations, and most importantly for "impact" as citations are adjusted for the impact that the most influential journals have on the profession. To correct for the impact of the journal we have broadly followed the eigenfactor methodology of Liebowitz and Palmer (1984), see also Laband and Piette, 1994 and Kalaitzidakis, Mamuneas and Stengos (2003). This methodology is based on an iterative procedure which we briefly outline below.

Let $C_{i j}$ be the number of citations to journal $i$ from journal $j, n$ the number 
of journals in our list and $Z_{i}$ a factor adjusting for the size of a journal. The $t$ iteration is given by

$$
I_{i, t}=\frac{\sum_{j=1}^{n} C_{i j}}{Z_{i}} I_{j, t-1},
$$

where

$$
I_{i, 0}=\frac{\sum_{j=1}^{n} C_{i j}}{Z_{i}}
$$

This process usually converges after a number of iterations, usually not more than 10 to 15 iterations The results reported in the tables have used no more than on 50 iterations in each case. Below we will discuss the results of these rankings.

\section{Journal Rankings and the Relative ranking of the CJE}

In Table 1, we present the impact adjusted journal rankings based on the above procedure and the corrections for self-citations and age of journal, both with and without adjustment for journal size for the final year of our analysis, 2008. In previous studies, journal size was adjusted using the total number of characters published per year, calculated as the number of characters per page times the average number of pages published. However, in this paper we correct for size by using citations per article. This is a more appropriate measure, since citations are attributed to articles irrespective of their size. The second column in Table 1 presents the impact adjusted but size unadjusted rankings, while the third column presents the impact and size adjusted rankings, using citations per article to adjust for size. JCR provides information for the number of articles per journal for most of the journals that make up the set of journals in the economics category of $J C R$ in each of the years for the 2003 to 2008 period. We have standardized the top journal, American Economic Review to be equal to 100. The following observations are worth making. There are a number of new journals that have made their mark very quickly since their appearance in the

profession. For example the Journal of the European Economics Association is 
ranked 19th, the Review of Economic Dynamics is 24th and the Journal of Economic Growth is 26th. These journals are fairly new and they were not ranked in the Kalaitzidakis et al (2003) study. Other journals not ranked in that study such as Econometric Reviews and Empirical Economics are now ranked better than the median, in the 68th and 89th position respectively. The median in this case is Energy Economics as it ranks 105th out of 209 journals. Among the top journals it is worth noting the substantial relative improvements of the Journal of International Economics, the Journal of Public Economics and the Economic Journal.

Table 2 presents all the relative impact and size adjusted rankings for all the years between 2003 and 2008. Note that the total number of journals differs between the different years as there are new entrants all the time. In fact the Journal of the European Economics Association only entered the rankings in 2007 as it made its inaugural appearance in 2003. It is quite remarkable that it has attained just a high ranking position within such a short time. It is interesting to see that the high relative ranking of newer journals such as the Review of Economic Dynamics and the Journal of Economic Growth has been fairly stable in the top tier throughout the period. The list of top 30 to 40 journals that comprises the average list of the top twenty percent of journals over the period has remained also fairly stable with the exception of 2005 where there have been some fluctuations. The top journal over the period is the American Economic Review coming first in all years except in 2003, with the Quarterly Journal of Economics coming overall second and the Journal of Political Economy, Econometrica and the Review of Economic Studies taking the other three spots in the top five.

In Table 1, the CJE is ranked 40th out of 209 journals, whereas in the Kalaitzidakis, Mamuneas and Stengos (2003) study it was ranked 42nd out of a group of 159. In Table 2, we can see that its relative position has remained relatively stable in the top quartile group, except for 2005 when its ranking fell to the top thirty percent from the top twenty percent group in the previous year, taking the 54th position out of 175 . However, overall the mean geometric rank of 
the CJE places either in or very close to the top twenty percent of journals. This overall ranking shows a marked improvement, especially when seen in a historical context. Recall, that the CJE was ranked in the Liebowitz and Palmer (1984) study as just outside the top quartile (28th out of 108 journals), then it slipped to about the median in the Laband and Piette (1994) ranking, where it fell to the 62 nd position out of 130 journals. It did recover to nearly the top quartile in Kalaitzidakis, Mamuneas and Stengos (2003), reaching the 42nd position out of a set of 159 . The results for the 2003 to 2008 period suggest that the improvement found in the Kalaitzidakis, Mamuneas and Stengos (2003) ranking has not just been maintained, but also improved upon. Figure 1, displays the relative quantile position of the CJE over the period 2003-2008 and it appears, that apart from the year 2005, the steady state position is in the top twenty percentile. The fact that we have used a rolling window of years between 2003 and 2008, for each year counting the number of citations of articles published in the previous ten years renders the present study robust to short run fluctuations that may arise. We are able to obtain a smoother longer view of the evolution of rankings in the period under consideration and avoid the inherent randomness that may exist at any particular year, even though using the rolling window methodology does not totally preclude the presence of outliers as it has been seen by the 2005 year rankings that differ from the rest. However, the methodology adopted here allows up to be more confident about the robustness of our results. This suggests that having solidified a ranking in the top twenty percent of journals, the CJE can now aim at emulating the strong performance of the top generalist journals that make part of the top ten percentile of journals. Perhaps, the success of the Journal of the European Economic Association which achieved a rapid climb in the rankings ladder, even though it only started in 2003 can act as an example to follow. 


\section{Conclusion}

We have conducted an update of the ranking of economic journals over the period 2003 to 2008 to that obtained by Kalaitzidakis, Mamuneas and Stengos (2003). Our present study differs methodologically from that earlier study in an important dimension. We use a rolling window of years between 2003 and 2008 , for each year counting the number of citations of articles published in the previous ten years. This allows us to obtain a smoother longer view of the evolution of rankings in the period under consideration and avoid the inherent randomness that may exist at any particular year. Using this framework we proceed to examine the relative ranking of the Canadian Journal of Economics over time. We find the Canadian Journal not only to maintain its relative position, but to also improve it over time. 


\section{References}

Kalaitzidakis, P., Mamuneas,. T. and Stengos, T. 2003, "Rankings of Academic Journals and Institutions in Economics," Journal of the European Economic Association, 1, 1346-1366.

Kóczy, L. A. and M. Strobel (2007), "The ranking of Economics Journals by a Tournament Method" unpublished manuscript.

Kodrzycki, Y.K. and P. Yu (2006), "New Approaches to Ranking Economic Journals," Contributions to Economic Analysis and Policy 5, art. 24

Laband, D. and Piette, M. 1994, "The Relative Impact of Economic Journals," Journal of Economic Literature, 32, 640-666.

Liebowitz, S. J. and Palmer, J. P., 1984, "Assessing the Relative Impacts of Economic Journals," Journal of Economic Literature, 22(1), 77-88

Liner, G.H. and M. Amin (2006), "Methods of ranking Economics Journals," Atlantic Economics Journal, 32, 140-149.

Palacio-Huerta, I. and O. Volij (2004), "The Measurement of Intellectual Influence," Econometrica 72, 963-977.

Ritzberger, K. (2008), "A Ranking of Journals in Economics and related Fields," German Economic Review, 9, 4, 402-430. 
Table 1: Journal Rankings, 2008

Impact, Age and Self Citations Adjusted

\begin{tabular}{|c|c|c|c|}
\hline Rank* $^{*}$ & Journal Abbreviation & $\begin{array}{l}\text { Citations } \\
\text { Index }\end{array}$ & $\begin{array}{c}\text { Citations/Article } \\
\text { Index }\end{array}$ \\
\hline 1 & AM ECON REV & 100.0000 & 100.0000 \\
\hline 2 & Q J ECON & 75.9197 & 59.6309 \\
\hline 3 & ECONOMETRICA & 66.0654 & 44.7797 \\
\hline 4 & J POLIT ECON & 53.8725 & 41.4496 \\
\hline 5 & REV ECON STUD & 44.1817 & 32.6611 \\
\hline 6 & J MONETARY ECON & 34.6689 & 27.8149 \\
\hline 7 & REV ECON STAT & 28.7777 & 24.2411 \\
\hline 8 & J ECON THEORY & 32.6343 & 22.5192 \\
\hline 9 & J PUBLIC ECON & 22.6121 & 22.1975 \\
\hline 10 & ECON J & 21.9844 & 20.8051 \\
\hline 11 & J ECON PERSPECT & 20.5835 & 19.1574 \\
\hline 12 & J INT ECON & 22.2429 & 19.1372 \\
\hline 13 & J ECON LIT & 22.8814 & 18.3493 \\
\hline 14 & J ECONOMETRICS & 17.4621 & 16.1703 \\
\hline 15 & J FINANC ECON & 16.7346 & 15.6500 \\
\hline 16 & EUR ECON REV & 17.8454 & 14.9099 \\
\hline 17 & RAND J ECON & 15.8823 & 12.9813 \\
\hline 18 & INT ECON REV & 16.5091 & 12.4167 \\
\hline 19 & J EUR ECON ASSOC & 13.9716 & 12.1464 \\
\hline 20 & GAME ECON BEHAV & 18.5236 & 12.0176 \\
\hline 21 & J MONEY CREDIT BANK & 15.0424 & 11.9505 \\
\hline 22 & ECON LETT & 13.4250 & 10.3591 \\
\hline 23 & J DEV ECON & 10.3872 & 10.0930 \\
\hline 24 & REV ECON DYNAM & 13.7037 & 9.0212 \\
\hline 25 & J LABOR ECON & 9.5469 & 8.8440 \\
\hline 26 & J ECON GROWTH & 8.0999 & 8.5603 \\
\hline 27 & J HUM RESOUR & 8.1728 & 7.5735 \\
\hline 28 & J ECON DYN CONTROL & 11.0127 & 7.3868 \\
\hline 29 & J ECON BEHAV ORGAN & 10.3773 & 7.3266 \\
\hline 30 & J BUS ECON STAT & 9.0874 & 6.9219 \\
\hline 31 & J HEALTH ECON & 5.8657 & 6.5065 \\
\hline 32 & $\mathrm{~J}$ APPL ECONOM & 8.0757 & 5.8026 \\
\hline 33 & BROOKINGS PAP ECO AC & 5.6726 & 5.0751 \\
\hline 34 & J URBAN ECON & 4.7543 & 4.9170 \\
\hline 35 & WORLD BANK ECON REV & 5.1088 & 4.9032 \\
\hline 36 & ECON THEOR & 8.1529 & 4.8327 \\
\hline 37 & SCAND J ECON & 4.8654 & 4.5411 \\
\hline 38 & J ECON HIST & 3.5874 & 4.4874 \\
\hline 39 & OXFORD ECON PAP & 3.8591 & 3.8461 \\
\hline 40 & CAN J ECON & 4.3848 & 3.7659 \\
\hline 41 & ECON INQ & 3.8806 & 3.6658 \\
\hline 42 & ECON POLICY & 3.9903 & 3.6458 \\
\hline
\end{tabular}


Table 1 (cont'd): Journal Rankings, 2008

\begin{tabular}{|c|c|c|c|}
\hline Rank* $^{*}$ & Journal Abbreviation & $\begin{array}{l}\text { Citations } \\
\text { Index }\end{array}$ & $\begin{array}{c}\text { Citations/Article } \\
\text { Index }\end{array}$ \\
\hline 43 & ECONOMET THEOR & 5.5067 & 3.6233 \\
\hline 44 & INT J IND ORGAN & 5.0477 & 3.6232 \\
\hline 45 & PUBLIC CHOICE & 4.1305 & 3.5188 \\
\hline 46 & J LAW ECON & 3.1301 & 3.4535 \\
\hline 47 & WORLD DEV & 3.4692 & 3.3347 \\
\hline 48 & J LAW ECON ORGAN & 3.6312 & 3.3122 \\
\hline 49 & J IND ECON & 4.2225 & 3.0808 \\
\hline 50 & LABOUR ECON & 2.8099 & 3.0583 \\
\hline 51 & J RISK UNCERTAINTY & 3.6232 & 2.7147 \\
\hline 52 & OXFORD B ECON STAT & 2.8967 & 2.6638 \\
\hline 53 & J POPUL ECON & 2.2502 & 2.5774 \\
\hline 54 & J ECON MANAGE STRAT & 3.4349 & 2.5741 \\
\hline 55 & EXPLOR ECON HIST & 2.2457 & 2.5673 \\
\hline 56 & J BANK FINANC & 3.2741 & 2.5278 \\
\hline 57 & NATL TAX J & 2.8867 & 2.2927 \\
\hline 58 & EXP ECON & 3.7882 & 2.2618 \\
\hline 59 & J ENVIRON ECON MANAG & 2.7899 & 2.2128 \\
\hline 60 & ECONOMICA & 2.3883 & 2.1974 \\
\hline 61 & ECON EDUC REV & 1.7651 & 2.1917 \\
\hline 62 & REG SCI URBAN ECON & 2.4631 & 2.1822 \\
\hline 63 & J FINANC QUANT ANAL & 3.5311 & 2.1518 \\
\hline 64 & J COMP ECON & 1.5621 & 2.0666 \\
\hline 65 & IMF STAFF PAPERS & 2.3392 & 2.0036 \\
\hline 66 & MACROECON DYN & 2.8780 & 1.9598 \\
\hline 67 & OXFORD REV ECON POL & 2.3646 & 1.9585 \\
\hline 68 & ECONOMET REV & 2.8229 & 1.9504 \\
\hline 69 & ECON DEV CULT CHANGE & 1.7388 & 1.9336 \\
\hline 70 & FED RESERVE BANK ST & 1.9599 & 1.8865 \\
\hline 71 & WORLD ECON & 2.4915 & 1.8622 \\
\hline 72 & APPL ECON & 2.5705 & 1.8458 \\
\hline 73 & SOUTH ECON J & 2.2362 & 1.8202 \\
\hline 74 & INT TAX PUBLIC FINAN & 2.1760 & 1.7582 \\
\hline 75 & ECONOMET J & 1.8927 & 1.7492 \\
\hline 76 & HEALTH ECON & 2.2859 & 1.7352 \\
\hline 77 & J ACCOUNT ECON & 2.4358 & 1.7242 \\
\hline 78 & AM J AGR ECON & 2.2389 & 1.6074 \\
\hline 79 & SOC CHOICE WELFARE & 2.7923 & 1.5782 \\
\hline 80 & J MATH ECON & 3.0650 & 1.4907 \\
\hline 81 & REV INCOME WEALTH & 1.4476 & 1.4723 \\
\hline 82 & J ECON SURV & 1.3177 & 1.3606 \\
\hline 83 & INT J GAME THEORY & 2.2777 & 1.3435 \\
\hline 84 & ECON HIST REV & 0.7134 & 1.3281 \\
\hline
\end{tabular}


Table 1 (cont'd): Journal Rankings, 2008

\begin{tabular}{|c|c|c|c|}
\hline Rank* $^{*}$ & Journal Abbreviation & $\begin{array}{l}\text { Citations } \\
\text { Index }\end{array}$ & $\begin{array}{c}\text { Citations/Article } \\
\text { Index }\end{array}$ \\
\hline 85 & ENVIRON RESOUR ECON & 1.4731 & 1.0720 \\
\hline 86 & ECOL ECON & 0.9905 & 1.0327 \\
\hline 87 & ENERG J & 1.2995 & 1.0138 \\
\hline 88 & WORLD BANK RES OBSER & 0.7120 & 0.9904 \\
\hline 89 & EMPIR ECON & 1.2779 & 0.9442 \\
\hline 90 & J POLICY ANAL MANAG & 1.1680 & 0.8882 \\
\hline 91 & J MACROECON & 1.2206 & 0.8850 \\
\hline 92 & LAND ECON & 1.4541 & 0.8577 \\
\hline 93 & SCOT J POLIT ECON & 0.9496 & 0.8563 \\
\hline 94 & MANCH SCH & 1.4848 & 0.8555 \\
\hline 95 & J DEV STUD & 1.0339 & 0.8383 \\
\hline 96 & ECON TRANSIT & 0.8951 & 0.8179 \\
\hline 97 & J REAL ESTATE FINANC & 0.9915 & 0.7834 \\
\hline 98 & J ECON & 0.9784 & 0.7697 \\
\hline 99 & J JPN INT ECON & 1.1596 & 0.7313 \\
\hline 100 & J ECON GEOGR & 1.0113 & 0.7306 \\
\hline 101 & JCMS-J COMMON MARK S & 0.3944 & 0.7062 \\
\hline 102 & J ECON PSYCHOL & 1.1251 & 0.7036 \\
\hline 103 & INT J FORECASTING & 0.6462 & 0.7026 \\
\hline 104 & REV WORLD ECON & 0.6590 & 0.6111 \\
\hline 105 & ENERG ECON & 0.4914 & 0.5989 \\
\hline 106 & REV IND ORGAN & 0.6634 & 0.5790 \\
\hline 107 & APPL ECON LETT & 1.1622 & 0.5013 \\
\hline 108 & J INST THEOR ECON & 0.7989 & 0.4872 \\
\hline 109 & J REGUL ECON & 0.7340 & 0.4717 \\
\hline 110 & MATH FINANC & 1.0203 & 0.4396 \\
\hline 111 & RESOUR ENERGY ECON & 0.7628 & 0.4388 \\
\hline 112 & ECON MODEL & 0.6127 & 0.4330 \\
\hline 113 & AGR ECON-BLACKWELL & 0.6472 & 0.4286 \\
\hline 114 & KYKLOS & 0.6378 & 0.4181 \\
\hline 115 & J REGIONAL SCI & 0.4334 & 0.3933 \\
\hline 116 & INT REV LAW ECON & 0.3501 & 0.3802 \\
\hline 117 & J PROD ANAL & 0.7376 & 0.3802 \\
\hline 118 & QUANT FINANC & 1.0901 & 0.3706 \\
\hline 119 & THEOR DECIS & 0.6114 & 0.3630 \\
\hline 120 & REV DEV ECON & 0.5045 & 0.3563 \\
\hline 121 & CONTEMP ECON POLICY & 0.3839 & 0.3473 \\
\hline 122 & J HOUS ECON & 0.4423 & 0.3395 \\
\hline 123 & FISC STUD & 0.2995 & 0.3295 \\
\hline 124 & OPEN ECON REV & 0.3330 & 0.3190 \\
\hline 125 & ECON HUM BIOL & 0.4697 & 0.3005 \\
\hline 126 & REAL ESTATE ECON & 0.2464 & 0.2940 \\
\hline
\end{tabular}


Table 1 (cont'd): Journal Rankings, 2008

\begin{tabular}{|c|c|c|c|}
\hline Rank $^{*}$ & Journal Abbreviation & $\begin{array}{l}\text { Citations } \\
\text { Index }\end{array}$ & $\begin{array}{l}\text { Citations/Article } \\
\text { Index }\end{array}$ \\
\hline 127 & FINANZARCHIV & 0.3260 & 0.2889 \\
\hline 128 & JPN ECON REV & 0.6226 & 0.2861 \\
\hline 129 & ECON REC & 0.3768 & 0.2669 \\
\hline 130 & QME-QUANT MARK ECON & 0.5527 & 0.2645 \\
\hline 131 & J POLICY MODEL & 0.3570 & 0.2561 \\
\hline 132 & SMALL BUS ECON & 0.2934 & 0.2528 \\
\hline 133 & REV AGR ECON & 0.3082 & 0.2521 \\
\hline 134 & SPAN ECON REV & 0.2559 & 0.2495 \\
\hline 135 & IND CORP CHANGE & 0.4517 & 0.2432 \\
\hline 136 & J ECON EDUC & 0.4774 & 0.2382 \\
\hline 137 & CESIFO ECON STUD & 0.2907 & 0.2374 \\
\hline 138 & CHINA ECON REV & 0.2529 & 0.2304 \\
\hline 139 & J AFR ECON & 0.2218 & 0.2263 \\
\hline 140 & J RISK INSUR & 0.3939 & 0.2121 \\
\hline 141 & J TRANSP ECON POLICY & 0.1964 & 0.2090 \\
\hline 142 & FOOD POLICY & 0.2948 & 0.2024 \\
\hline 143 & STUD NONLINEAR DYN E & 0.3073 & 0.1771 \\
\hline 144 & ECONOMIST-NETHERLAND & 0.2598 & 0.1592 \\
\hline 145 & J AGR RESOUR ECON & 0.2931 & 0.1476 \\
\hline 146 & S AFR J ECON & 0.0727 & 0.1475 \\
\hline 147 & CAMB J ECON & 0.1355 & 0.1361 \\
\hline 148 & EUR REV AGRIC ECON & 0.2524 & 0.1334 \\
\hline 149 & J EVOL ECON & 0.3517 & 0.1270 \\
\hline 150 & ECON GEOGR & 0.1122 & 0.1203 \\
\hline 151 & ECON PHILOS & 0.2342 & 0.1146 \\
\hline 152 & PAC ECON REV & 0.2622 & 0.1138 \\
\hline 153 & REV INT POLIT ECON & 0.1036 & 0.1116 \\
\hline 154 & JPN WORLD ECON & 0.1696 & 0.1110 \\
\hline 155 & J AGR ECON & 0.1973 & 0.1053 \\
\hline 156 & AUST J AGR RESOUR EC & 0.1523 & 0.0945 \\
\hline 157 & PORT ECON J & 0.0832 & 0.0904 \\
\hline 158 & INSUR MATH ECON & 0.1643 & 0.0791 \\
\hline 159 & INF ECON POLICY & 0.0997 & 0.0763 \\
\hline 160 & J POLICY REFORM & 0.0713 & 0.0749 \\
\hline 161 & J REAL ESTATE RES & 0.0419 & 0.0723 \\
\hline 162 & EMERG MARK FINANC TR & 0.0747 & 0.0645 \\
\hline 163 & B INDONES ECON STUD & 0.0761 & 0.0608 \\
\hline 164 & DEFENCE PEACE ECON & 0.1511 & 0.0536 \\
\hline 165 & AM J ECON SOCIOL & 0.1868 & 0.0528 \\
\hline 166 & CAN J AGR ECON & 0.0990 & 0.0489 \\
\hline 167 & TRIMEST ECON & 0.0854 & 0.0487 \\
\hline 168 & ECON SOC & 0.0437 & 0.0430 \\
\hline
\end{tabular}


Table 1 (cont'd): Journal Rankings, 2008

\begin{tabular}{|c|c|c|c|}
\hline Rank* $^{*}$ & Journal Abbreviation & $\begin{array}{l}\text { Citations } \\
\text { Index }\end{array}$ & $\begin{array}{c}\text { Citations/Article } \\
\text { Index }\end{array}$ \\
\hline 169 & INDEP REV & 0.1014 & 0.0418 \\
\hline 170 & J APPL ECON & 0.0368 & 0.0413 \\
\hline 171 & GENEVA RISK INS REV & 0.0689 & 0.0401 \\
\hline 172 & JAHRB NATL STAT & 0.0281 & 0.0389 \\
\hline 173 & AUST ECON HIST REV & 0.0185 & 0.0384 \\
\hline 174 & J ECON ISSUES & 0.0666 & 0.0360 \\
\hline 175 & FEM ECON & 0.0417 & 0.0301 \\
\hline 176 & AUST ECON REV & 0.0470 & 0.0300 \\
\hline 177 & J FOREST ECON & 0.0260 & 0.0270 \\
\hline 178 & TIJDSCHR ECON SOC GE & 0.0192 & 0.0266 \\
\hline 179 & EASTERN EUR ECON & 0.0179 & 0.0253 \\
\hline 180 & ASTIN BULL & 0.0838 & 0.0245 \\
\hline 181 & INVEST ECON-SPAIN & 0.0683 & 0.0223 \\
\hline 182 & HITOTSUB J ECON & 0.0312 & 0.0221 \\
\hline 183 & J AGRAR CHANGE & 0.0398 & 0.0197 \\
\hline 184 & REV ECON POLIT & 0.0122 & 0.0192 \\
\hline 185 & REV ECON APL-SPAIN & 0.0144 & 0.0190 \\
\hline 186 & S AFR J ECON MANAG S & 0.0084 & 0.0179 \\
\hline 187 & NEW POLIT ECON & 0.0068 & 0.0171 \\
\hline 188 & FUTURES & 0.0462 & 0.0126 \\
\hline 189 & POST-COMMUNIST ECON & 0.0072 & 0.0123 \\
\hline 190 & J ECON POLICY REFORM & 0.0048 & 0.0115 \\
\hline 191 & J POST KEYNESIAN EC & 0.0220 & 0.0106 \\
\hline 192 & DEV ECON & 0.0272 & 0.0090 \\
\hline 193 & HACIENDA PUBLICA ESP & 0.0118 & 0.0086 \\
\hline 194 & INVEST ECON-MEX & 0.0284 & 0.0081 \\
\hline 195 & INT J TRANSP ECON & 0.0195 & 0.0075 \\
\hline 196 & WORK EMPLOY SOC & 0.0152 & 0.0067 \\
\hline 197 & ECON DEV Q & 0.0067 & 0.0067 \\
\hline 198 & CHINA WORLD ECON & 0.0073 & 0.0037 \\
\hline 199 & HIST POLIT ECON & 0.0042 & 0.0036 \\
\hline 200 & J MEDIA ECON & 0.0013 & 0.0024 \\
\hline 201 & EUR J HIST ECON THOU & 0.0008 & 0.0013 \\
\hline 202 & POLIT EKON & 0.0011 & 0.0009 \\
\hline 203 & POST-SOV AFF & 0.0003 & 0.0006 \\
\hline 204 & REV ETUD COMP EST-O & 0.0001 & 0.0005 \\
\hline 205 & EUROPE-ASIA STUD & 0.0000 & 0.0004 \\
\hline 206 & EKON CAS & 0.0001 & 0.0002 \\
\hline 207 & DESARROLLO ECON & 0.0001 & 0.0001 \\
\hline 208 & EKON SAMF TIDSKR & 0.0000 & 0.0000 \\
\hline 209 & TRANSFORM BUS ECON & 0.0000 & 0.0000 \\
\hline
\end{tabular}

* Rank is based on the Citations per Article Index 
Table 2: Journal Rankings 2003-2008

Based on Impact adjusted for Age and Self Citations, Citations per Article

\begin{tabular}{|c|c|c|c|c|c|c|c|}
\hline Journal Abbreviation & 2008 & 2007 & 2006 & 2005 & 2004 & 2003 & Mean* \\
\hline ADV ECONOMETRICS & & & & 119 & 97 & 86 & 100 \\
\hline AGR ECON-BLACKWELL & 113 & 122 & 124 & 117 & 89 & 93 & 109 \\
\hline AM ECON REV & 1 & 1 & 1 & 1 & 1 & 2 & 1 \\
\hline AM J AGR ECON & 78 & 62 & 80 & 63 & 32 & 67 & 61 \\
\hline AM J ECON SOCIOL & 165 & 159 & 160 & 141 & 138 & 146 & 151 \\
\hline APPL ECON & 72 & 70 & 75 & 72 & 68 & 63 & 70 \\
\hline APPL ECON LETT & 107 & 101 & 110 & 123 & 111 & 118 & 111 \\
\hline ASTIN BULL & 180 & 176 & & & & & 178 \\
\hline AUST ECON HIST REV & 173 & & & & & & 173 \\
\hline AUST ECON REV & 176 & & & & & & 176 \\
\hline AUST J AGR RESOUR EC & 156 & 150 & 154 & 126 & 139 & 141 & 144 \\
\hline B INDONES ECON STUD & 163 & 144 & 163 & 159 & 141 & 144 & 152 \\
\hline BROOKINGS PAP ECO AC & 33 & 35 & 25 & 31 & 27 & 17 & 27 \\
\hline CAMB J ECON & 147 & 135 & 137 & 135 & 121 & 116 & 131 \\
\hline CAN J AGR ECON & 166 & & & & & & 166 \\
\hline CAN J ECON & 40 & 45 & 41 & 54 & 31 & 37 & 41 \\
\hline CESIFO ECON STUD & 137 & 133 & & & & & 135 \\
\hline CHINA ECON REV & 138 & 118 & 142 & 81 & 119 & 123 & 118 \\
\hline CHINA WORLD ECON & 198 & & & & & & 198 \\
\hline CONTEMP ECON POLICY & 121 & 111 & 129 & 115 & 134 & 95 & 117 \\
\hline DEFENCE PEACE ECON & 164 & 140 & 136 & 162 & 116 & & 142 \\
\hline DESARROLLO ECON & 207 & 185 & 172 & 149 & 146 & 168 & 170 \\
\hline DEV ECON & 192 & 154 & 135 & 153 & 151 & 148 & 155 \\
\hline EASTERN EUR ECON & 179 & 179 & 149 & 164 & 160 & 151 & 163 \\
\hline ECOL ECON & 86 & 64 & 97 & 110 & 72 & 96 & 86 \\
\hline ECON DEV CULT CHANGE & 69 & 66 & 95 & 62 & 48 & 94 & 70 \\
\hline ECON DEV Q & 197 & 139 & 162 & 170 & 154 & 149 & 161 \\
\hline ECON EDUC REV & 61 & 76 & 68 & 83 & 60 & 73 & 70 \\
\hline ECON GEOGR & 150 & 162 & 133 & 131 & 149 & 154 & 146 \\
\hline ECON HIST REV & 84 & 136 & 123 & 71 & 98 & 104 & 100 \\
\hline ECON HUM BIOL & 125 & & & & & & 125 \\
\hline ECON INQ & 41 & 43 & 42 & 40 & 41 & 51 & 43 \\
\hline ECON J & 10 & 7 & 9 & 10 & 11 & 14 & 10 \\
\hline ECON LETT & 22 & 23 & 21 & 19 & 24 & 23 & 22 \\
\hline ECON MODEL & 112 & 131 & 114 & 125 & 125 & 137 & 124 \\
\hline ECON PHILOS & 151 & 158 & 130 & 152 & 110 & 145 & 140 \\
\hline ECON PLAN & & & & & & 121 & 121 \\
\hline ECON POLICY & 42 & 51 & 54 & 67 & 58 & 52 & 53 \\
\hline ECON REC & 129 & 138 & 102 & 136 & 143 & 113 & 126 \\
\hline ECON SOC & 168 & 167 & 151 & 148 & 159 & 156 & 158 \\
\hline ECON THEOR & 36 & 33 & 27 & 30 & 37 & 30 & 32 \\
\hline ECON TRANSIT & 96 & 83 & 93 & 75 & 91 & 69 & 84 \\
\hline ECONOMET J & 75 & 67 & & & & & 71 \\
\hline ECONOMET REV & 68 & 80 & & & & & 74 \\
\hline
\end{tabular}


Table 2 (cont'd) Journal Rankings 2003-2008

\begin{tabular}{|c|c|c|c|c|c|c|c|}
\hline Journal Abbreviation & 2008 & 2007 & 2006 & 2005 & 2004 & 2003 & Mean* \\
\hline ECONOMET THEOR & 43 & 38 & 40 & 35 & 34 & 26 & 36 \\
\hline ECONOMETRICA & 3 & 4 & 3 & 4 & 4 & 4 & 4 \\
\hline ECONOMICA & 60 & 60 & 53 & 55 & 54 & 66 & 58 \\
\hline ECONOMIST-NETHERLAND & 144 & 157 & 117 & 137 & 130 & 140 & 137 \\
\hline EKON CAS & 206 & 185 & 168 & 171 & 170 & 152 & 175 \\
\hline EKON SAMF TIDSKR & 208 & 185 & 174 & 171 & 166 & 157 & 176 \\
\hline EMERG MARK FINANC TR & 162 & 151 & 152 & 156 & & & 155 \\
\hline EMPIR ECON & 89 & 91 & & & & & 90 \\
\hline ENERG ECON & 105 & 93 & 122 & 144 & 129 & 138 & 120 \\
\hline ENERG J & 87 & 74 & 91 & 91 & 112 & 75 & 87 \\
\hline ENVIRON RESOUR ECON & 85 & 85 & 86 & 85 & 94 & 89 & 87 \\
\hline EUR ECON REV & 16 & 16 & 12 & 13 & 8 & 11 & 12 \\
\hline EUR J HIST ECON THOU & 201 & 156 & & & & & 177 \\
\hline EUR REV AGRIC ECON & 148 & 146 & 148 & 132 & 76 & 136 & 128 \\
\hline EURASIAN GEOGR ECON & & & 171 & 157 & 165 & 167 & 165 \\
\hline EUROPE-ASIA STUD & 205 & 103 & 155 & 90 & 164 & 155 & 140 \\
\hline EXP ECON & 58 & 48 & 70 & & & & 58 \\
\hline EXPLOR ECON HIST & 55 & 82 & 74 & 57 & 93 & 85 & 73 \\
\hline FED RESERVE BANK ST & 70 & & & & & & 70 \\
\hline FEM ECON & 175 & 161 & 164 & 155 & 152 & 133 & 156 \\
\hline FINANZARCHIV & 127 & & & & & & 127 \\
\hline FISC STUD & 123 & 109 & 105 & 106 & 135 & 110 & 114 \\
\hline FOOD POLICY & 142 & 149 & 143 & 121 & 92 & 139 & 129 \\
\hline FUTURES & 188 & 177 & 161 & 171 & 161 & 159 & 169 \\
\hline GAME ECON BEHAV & 20 & 24 & 19 & 17 & 20 & 24 & 21 \\
\hline GENEVA PAP R I THEOR & & & 134 & 167 & & & 150 \\
\hline GENEVA RISK INS REV & 171 & 180 & 174 & & & & 175 \\
\hline HACIENDA PUBLICA ESP & 193 & & & & & & 193 \\
\hline HEALTH ECON & 76 & 90 & 82 & 76 & 84 & 100 & 84 \\
\hline HIST POLIT ECON & 199 & & & & & 163 & 180 \\
\hline HITOTSUB J ECON & 182 & 182 & 169 & 169 & 156 & 150 & 168 \\
\hline IMF STAFF PAPERS & 65 & 63 & 64 & 61 & 50 & 46 & 58 \\
\hline IND CORP CHANGE & 135 & 121 & 120 & 79 & 95 & & 108 \\
\hline INDEP REV & 169 & 165 & & & & & 167 \\
\hline INF ECON POLICY & 159 & 152 & 99 & 120 & 133 & 128 & 130 \\
\hline INSUR MATH ECON & 158 & 163 & 126 & 138 & 142 & 142 & 144 \\
\hline INT ECON REV & 18 & 17 & 14 & 15 & 17 & 20 & 17 \\
\hline INT J FORECASTING & 103 & 120 & 107 & 94 & 106 & 87 & 102 \\
\hline INT J GAME THEORY & 83 & 79 & 55 & 51 & 65 & 78 & 67 \\
\hline INT J IND ORGAN & 44 & 41 & 32 & 46 & 49 & 47 & 43 \\
\hline INT J TRANSP ECON & 195 & 175 & & & & & 185 \\
\hline INT REV LAW ECON & 116 & 108 & 98 & 93 & 117 & 114 & 107 \\
\hline INT TAX PUBLIC FINAN & 74 & 77 & 88 & 74 & 73 & 64 & 75 \\
\hline INVEST ECON-MEX & 194 & & & & & & 194 \\
\hline
\end{tabular}


Table 2 (cont'd) Journal Rankings 2003-2008

\begin{tabular}{|c|c|c|c|c|c|c|c|}
\hline Journal Abbreviation & 2008 & 2007 & 2006 & 2005 & 2004 & 2003 & Mean* \\
\hline INVEST ECON-SPAIN & 181 & 173 & & & & & 177 \\
\hline J ACCOUNT ECON & 77 & 75 & 44 & 66 & 86 & 38 & 62 \\
\hline J AFR ECON & 139 & 124 & 125 & 130 & 88 & 107 & 118 \\
\hline J AGR ECON & 155 & 153 & 144 & 134 & 123 & 125 & 138 \\
\hline J AGR RESOUR ECON & 145 & 143 & 128 & 128 & 100 & 132 & 128 \\
\hline J AGRAR CHANGE & 183 & & & & & & 183 \\
\hline J APPL ECON & 170 & 181 & & & & & 175 \\
\hline J APPL ECONOM & 32 & 26 & 38 & 34 & 36 & 29 & 32 \\
\hline J BANK FINANC & 56 & 42 & 52 & 43 & 38 & 33 & 43 \\
\hline J BUS ECON STAT & 30 & 32 & 26 & 22 & 25 & 21 & 26 \\
\hline J COMMON MARK STUD & & & & & 145 & & 145 \\
\hline J COMP ECON & 64 & 65 & 84 & 49 & 67 & 57 & 63 \\
\hline J DEV ECON & 23 & 19 & 23 & 24 & 15 & 25 & 21 \\
\hline J DEV STUD & 95 & 87 & 77 & & & & 86 \\
\hline $\mathrm{J}$ ECON & 98 & 125 & 90 & 96 & 103 & 129 & 106 \\
\hline J ECON BEHAV ORGAN & 29 & 25 & 33 & 26 & 33 & 40 & 31 \\
\hline J ECON DYN CONTROL & 28 & 34 & 31 & 29 & 39 & 27 & 31 \\
\hline J ECON EDUC & 136 & 132 & 116 & 124 & 82 & 120 & 117 \\
\hline J ECON GEOGR & 100 & 137 & 76 & 100 & 126 & & 106 \\
\hline J ECON GROWTH & 26 & 30 & 34 & 27 & 29 & 34 & 30 \\
\hline J ECON HIST & 38 & 46 & 49 & 42 & 61 & 41 & 46 \\
\hline J ECON ISSUES & 174 & 164 & 153 & 151 & 148 & 143 & 155 \\
\hline J ECON LIT & 13 & 10 & 11 & 9 & 14 & 12 & 11 \\
\hline J ECON MANAGE STRAT & 54 & 39 & 35 & 45 & 47 & 60 & 46 \\
\hline J ECON PERSPECT & 11 & 9 & 7 & 12 & 6 & 7 & 8 \\
\hline J ECON POLICY REFORM & 190 & & & & & & 190 \\
\hline J ECON PSYCHOL & 102 & 97 & 100 & 92 & 114 & 105 & 101 \\
\hline J ECON SURV & 82 & 78 & 108 & 109 & 124 & 126 & 103 \\
\hline J ECON THEORY & 8 & 12 & 6 & 6 & 12 & 16 & 9 \\
\hline J ECONOMETRICS & 14 & 11 & 18 & 18 & 10 & 6 & 12 \\
\hline J ENVIRON ECON MANAG & 59 & 52 & 51 & 47 & 43 & 54 & 51 \\
\hline J EUR ECON ASSOC & 19 & 22 & & & & & 20 \\
\hline J EVOL ECON & 149 & 130 & 131 & 97 & 132 & 91 & 120 \\
\hline J FINANC ECON & 15 & 15 & 15 & 14 & 19 & 10 & 14 \\
\hline J FINANC QUANT ANAL & 63 & 53 & 59 & 48 & 56 & 44 & 53 \\
\hline J FOREST ECON & 177 & 172 & & & & & 174 \\
\hline J HEALTH ECON & 31 & 47 & 36 & 39 & 40 & 70 & 42 \\
\hline J HOUS ECON & 122 & 148 & 87 & 86 & 90 & 112 & 105 \\
\hline J HUM RESOUR & 27 & 27 & 24 & 32 & 23 & 31 & 27 \\
\hline J IND ECON & 49 & 29 & 28 & 50 & 46 & 43 & 40 \\
\hline J INST THEOR ECON & 108 & 116 & 71 & 101 & 107 & 97 & 99 \\
\hline J INT ECON & 12 & 13 & 17 & 16 & 13 & 13 & 14 \\
\hline J JPN INT ECON & 99 & 95 & 106 & 80 & 81 & 71 & 88 \\
\hline J LABOR ECON & 25 & 20 & 20 & 28 & 22 & 28 & 24 \\
\hline
\end{tabular}


Table 2 (cont'd) Journal Rankings 2003-2008

\begin{tabular}{|c|c|c|c|c|c|c|c|}
\hline Journal Abbreviation & 2008 & 2007 & 2006 & 2005 & 2004 & 2003 & Mean* \\
\hline J LABOR ECON & 25 & 20 & 20 & 28 & 22 & 28 & 24 \\
\hline J LAW ECON & 46 & 37 & 43 & 41 & 44 & 42 & 42 \\
\hline J LAW ECON ORGAN & 48 & 36 & 47 & 33 & 51 & 39 & 42 \\
\hline J MACROECON & 91 & 104 & 111 & 107 & 108 & 106 & 104 \\
\hline J MATH ECON & 80 & 73 & 50 & 58 & 69 & 77 & 67 \\
\hline J MEDIA ECON & 200 & 185 & 173 & 147 & 171 & 162 & 172 \\
\hline J MONETARY ECON & 6 & 8 & 8 & 7 & 5 & 5 & 6 \\
\hline J MONEY CREDIT BANK & 21 & 28 & 29 & 21 & 28 & 15 & 23 \\
\hline J POLICY ANAL MANAG & 90 & 129 & & & & & 108 \\
\hline J POLICY MODEL & 131 & 119 & 119 & 140 & 122 & 131 & 127 \\
\hline J POLICY REFORM & 160 & & & & & & 160 \\
\hline J POLIT ECON & 4 & 3 & 4 & 3 & 3 & 3 & 3 \\
\hline J POPUL ECON & 53 & 69 & 60 & 69 & 83 & 88 & 69 \\
\hline J POST KEYNESIAN EC & 191 & 170 & 147 & 158 & 144 & 119 & 153 \\
\hline J PROD ANAL & 117 & 92 & 112 & 89 & 99 & 99 & 101 \\
\hline J PUBLIC ECON & 9 & 14 & 13 & 11 & 16 & 18 & 13 \\
\hline J REAL ESTATE FINANC & 97 & 106 & 78 & 68 & 104 & 74 & 87 \\
\hline J REAL ESTATE RES & 161 & & & & & & 161 \\
\hline J REGIONAL SCI & 115 & 99 & & & & & 107 \\
\hline J REGUL ECON & 109 & 105 & 37 & 98 & 102 & 61 & 80 \\
\hline J RISK INSUR & 140 & 127 & 94 & 116 & 96 & 115 & 114 \\
\hline J RISK UNCERTAINTY & 51 & 59 & 48 & 53 & 59 & 68 & 56 \\
\hline J TRANSP ECON POLICY & 141 & 81 & 141 & 127 & 136 & 117 & 122 \\
\hline J URBAN ECON & 34 & 31 & 30 & 36 & 42 & 48 & 36 \\
\hline J WORLD TRADE & & & & 129 & 150 & 161 & 146 \\
\hline JAHRB NATL STAT & 172 & 141 & 156 & 139 & 137 & 135 & 146 \\
\hline JCMS-J COMMON MARK S & 101 & 145 & 145 & 150 & & & 134 \\
\hline JPN ECON REV & 128 & 123 & 115 & 113 & 127 & 127 & 122 \\
\hline JPN WORLD ECON & 154 & 147 & 118 & 142 & 115 & 103 & 128 \\
\hline KYKLOS & 114 & 96 & 127 & 95 & 85 & 102 & 102 \\
\hline LABOUR ECON & 50 & 54 & 61 & 64 & 62 & 79 & 61 \\
\hline LAND ECON & 92 & 89 & 79 & 82 & 75 & 83 & 83 \\
\hline MACROECON DYN & 66 & 71 & 66 & 52 & 70 & 35 & 58 \\
\hline MANCH SCH & 94 & 110 & 104 & 122 & 109 & 98 & 106 \\
\hline MATH FINANC & 110 & 107 & 92 & 102 & 71 & 84 & 93 \\
\hline NATL TAX J & 57 & 61 & 46 & 37 & 52 & 36 & 47 \\
\hline NBER MACROECON ANNA & & & & 23 & 21 & 22 & 22 \\
\hline NEW ENGL ECON REV & & & 121 & 165 & 153 & 108 & 135 \\
\hline NEW POLIT ECON & 187 & 183 & 159 & 161 & & & 172 \\
\hline OPEN ECON REV & 124 & 142 & 109 & 146 & 147 & 134 & 133 \\
\hline OXFORD B ECON STAT & 52 & 55 & 63 & 70 & 55 & 56 & 58 \\
\hline OXFORD ECON PAP & 39 & 50 & 45 & 65 & 53 & 50 & 50 \\
\hline OXFORD REV ECON POL & 67 & 86 & 73 & 87 & 78 & 81 & 78 \\
\hline PAC ECON REV & 152 & 115 & & & & & 132 \\
\hline POLIT EKON & 202 & 185 & 165 & 171 & 168 & 32 & 134 \\
\hline
\end{tabular}


Table 2 (cont'd) Journal Rankings 2003-2008

\begin{tabular}{|c|c|c|c|c|c|c|c|}
\hline Journal Abbreviation & 2008 & 2007 & 2006 & 2005 & 2004 & 2003 & Mean* \\
\hline PORT ECON J & 157 & 128 & & & & & 142 \\
\hline POST-COMMUNIST ECON & 189 & 166 & 157 & 166 & 171 & 160 & 168 \\
\hline POST-SOV AFF & 203 & 174 & 167 & 145 & 162 & 165 & 168 \\
\hline POST-SOV GEOGR ECON & & & & & 118 & 124 & 121 \\
\hline PUBLIC CHOICE & 45 & 44 & 58 & 59 & 45 & 53 & 50 \\
\hline Q J ECON & 2 & 2 & 2 & 2 & 2 & 1 & 2 \\
\hline QME-QUANT MARK ECON & 130 & & & & & & 130 \\
\hline QUANT FINANC & 118 & 126 & 85 & 114 & & & 110 \\
\hline RAND J ECON & 17 & 18 & 16 & 20 & 18 & 19 & 18 \\
\hline REAL ESTATE ECON & 126 & 134 & 83 & 99 & 120 & 90 & 107 \\
\hline REG SCI URBAN ECON & 62 & 57 & 72 & 60 & 66 & 65 & 63 \\
\hline RESOUR ENERGY ECON & 111 & 112 & 101 & 103 & 113 & 109 & 108 \\
\hline REV AGR ECON & 133 & 155 & 146 & 133 & & & 141 \\
\hline REV DEV ECON & 120 & 113 & & & & & 116 \\
\hline REV ECON APL-SPAIN & 185 & & & & & & 185 \\
\hline REV ECON DYNAM & 24 & 21 & 22 & 25 & 35 & 45 & 28 \\
\hline REV ECON POLIT & 184 & 168 & & & & & 176 \\
\hline REV ECON STAT & 7 & 6 & 10 & 8 & 9 & 9 & 8 \\
\hline REV ECON STUD & 5 & 5 & 5 & 5 & 7 & 8 & 6 \\
\hline REV ETUD COMP EST-O & 204 & 185 & 170 & 171 & 169 & 164 & 177 \\
\hline REV INCOME WEALTH & 81 & 84 & 62 & 78 & 77 & 76 & 76 \\
\hline REV IND ORGAN & 106 & 88 & 67 & 84 & 87 & 58 & 80 \\
\hline REV INT POLIT ECON & 153 & 171 & 140 & 160 & 155 & 158 & 156 \\
\hline REV WORLD ECON & 104 & 114 & 132 & 108 & 158 & & 122 \\
\hline S AFR J ECON & 146 & 160 & 139 & 154 & 140 & 147 & 147 \\
\hline S AFR J ECON MANAG S & 186 & & & & & & 186 \\
\hline SCAND J ECON & 37 & 49 & 39 & 44 & 57 & 55 & 46 \\
\hline SCOT J POLIT ECON & 93 & 100 & 96 & 105 & 105 & 92 & 98 \\
\hline SMALL BUS ECON & 132 & 94 & 138 & 104 & 128 & 130 & 120 \\
\hline SOC CHOICE WELFARE & 79 & 68 & 69 & 73 & 74 & 82 & 74 \\
\hline SOUTH ECON J & 73 & 72 & 81 & 77 & 63 & 59 & 70 \\
\hline SPAN ECON REV & 134 & & & & & & 134 \\
\hline STUD NONLINEAR DYN E & 143 & 117 & 113 & 112 & 131 & 101 & 119 \\
\hline THEOR DECIS & 119 & 102 & 103 & 111 & 101 & 122 & 109 \\
\hline TIJDSCHR ECON SOC GE & 178 & 178 & 150 & 168 & 163 & 166 & 167 \\
\hline TRANSFORM BUS ECON & 208 & 185 & & & & & 196 \\
\hline TRIMEST ECON & 167 & 169 & 166 & 143 & 157 & 153 & 159 \\
\hline WELTWIRTSKH ARCH & & & & & 79 & 72 & 75 \\
\hline WORK EMPLOY SOC & 196 & 184 & 158 & 163 & 167 & 168 & 172 \\
\hline WORLD BANK ECON REV & 35 & 40 & 57 & 38 & 26 & 49 & 40 \\
\hline WORLD BANK RES OBSER & 88 & 98 & 89 & 118 & 80 & 111 & 96 \\
\hline WORLD DEV & 47 & 58 & 56 & 56 & 30 & 62 & 50 \\
\hline WORLD ECON & 71 & 56 & 65 & 88 & 64 & 80 & 70 \\
\hline Number of Journals & 209 & 191 & 175 & 175 & 172 & 169 & 219 \\
\hline
\end{tabular}




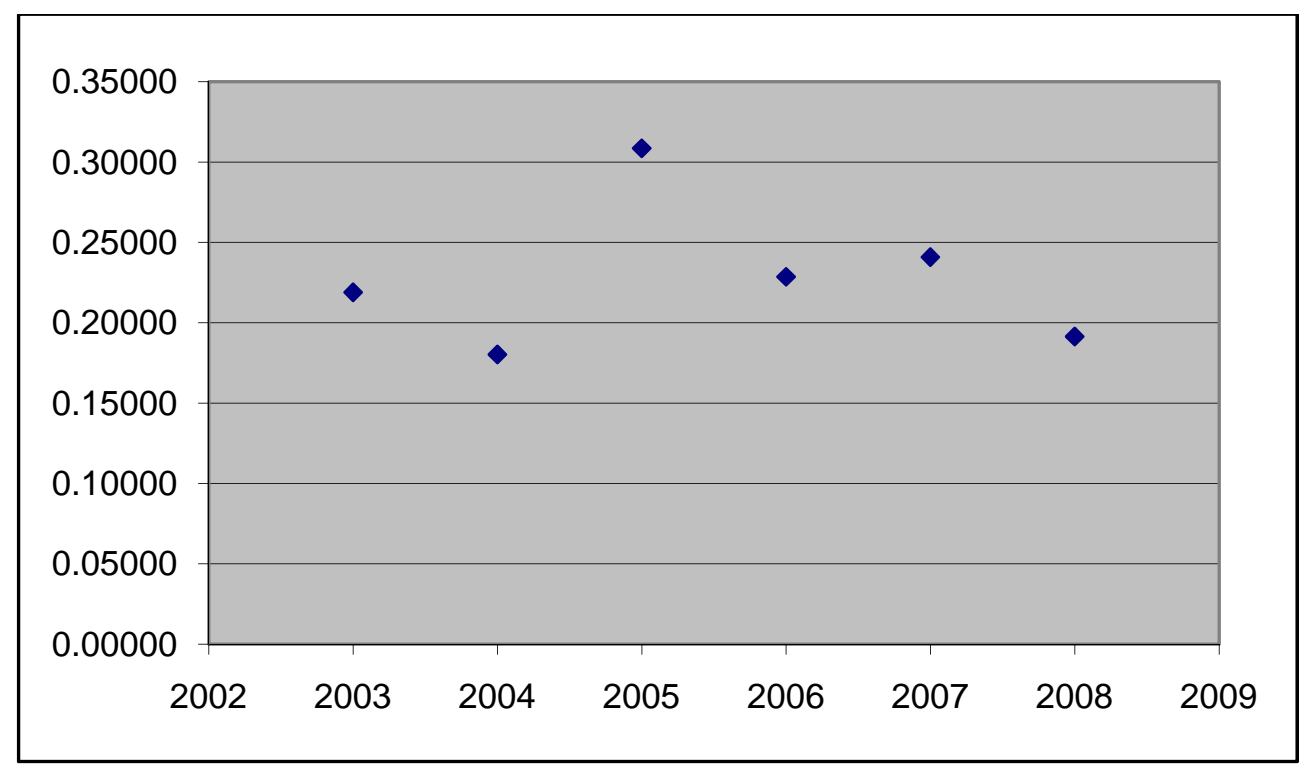

Figure1: The Canadian Journal of Economics Relative Ranking over Time 